\title{
Antarctic holothuroids from the Bellingshausen Sea, with descriptions of new species (Echinodermata: Holothuroidea)
}

\author{
P. MARK O'LOUGHLIN ${ }^{1}$, M. EUGENIA MANJÓN-CABEZA ${ }^{2} \&$ FRANCINA MOYA RUIZ $^{3}$ \\ ${ }^{1}$ Marine Science Department, Museum Victoria, GPO Box 666, Melbourne 3001, Australia. E-mail: pmo@bigpond.net.au \\ ${ }^{2}$ Animal Biology Department. Science Faculty. University of Malaga. Campus de Teatinos s/n. 29071-Malaga. Spain. \\ E-mail: mecloute@uma.es \\ ${ }^{3}$ Spanish Oceanographic Institute. Oceanographic centre of Malaga. Puerto Pesquero s/n. 29640-Fuengirola.Malaga. Spain. \\ E-mail: francina.moya@ma.ieo.es
}

\begin{abstract}
Three new species of holothuroids from the Antarctic Peninsula and Bellingshausen Sea are described, with O'Loughin \& Manjón-Cabeza as authors: dendrochirotids Cucumaria dudexa sp. nov., Psolicrux iuvenilesi sp. nov.; myriotrochid Myriotrochus hesperides sp. nov. Parathyonidium incertum Heding is discussed. Two synonymies for Antarctic holothuroids are formalised: Caespitugo citriformis Gutt is a junior synonym of Thyone scotiae Vaney; Caespitugo diversipes Gutt is a junior synonym of Cucumaria psolidiformis Vaney. Cucumaria armata Vaney is removed from inclusion in the Cucumaria georgiana (Lampert) group, and is a junior synonym of Cucumaria psolidiformis Vaney. A synonymy of Cucumaria aspera Vaney with Psolidium (Cucumaria) coatsi Vaney is rejected; Cucumaria aspera Vaney is referred to the Cucumaria georgiana (Lampert) group. Cucumaria conspicua Vaney is removed from synonymy with Psolidium (Cucumaria) coatsi Vaney, and is a junior synonym of Cucumaria psolidiformis Vaney. Thyone scotiae Vaney is referred to Crucella Gutt. Caespitugo Gutt is a junior synonym of Crucella Gutt. A new genus Cucamba O'Loughlin is erected; Cucumaria psolidiformis Vaney is referred to Cucamba O'Loughlin. A synonymy of Staurocucumis grandis (Vaney) with Staurocucumis turqueti (Vaney) is confirmed. The referral of Pseudocolochirus mollis Ludwig \& Heding to Psolidiella Mortensen is confirmed. Lists of contemporary synonymies for Antarctic holothuroid species and generic referrals for Antarctic dendrochirotid species are provided. A table of holothuroid species collected from the Antarctic Peninsula and Bellingshausen Sea by the Spanish BENTART-2003 and BENTART-2006 cruises is provided.
\end{abstract}

Key words: Bentart, Dendrochirotida, Myriotrochidae, new genus, new species, synonymies, generic referrals

\section{Introduction}

The University of Málaga currently holds a large collection of holothuroids from the Antarctic Peninsula and Bellingshausen Sea. These were collected by two Spanish Government expeditions, BENTART-2003 (30 January to 27 February 2003) and BENTART-2006 (20 January to 13 February 2006), using the Spanish R/V Hesperides. The goal of the BENTART expeditions was an integrated taxonomic and ecological study of the benthos of this Antarctic region.

During October of 2008 this large collection was studied, and the data collated by the authors and their student assistants from the University of Málaga. These data are in Table 1. Seven new species were recognized. Three are described in this work. The remaining four have been found in other Antarctic collections and will be described elsewhere. Mark O'Loughlin is responsible for the systematic decisions in this work. Eugenia Manjón-Cabeza is responsible for the specimens in this collection. Mark O'Loughlin is the author of a new genus, and Mark O'Loughlin and Eugenia Manjón-Cabeza are the authors of the new species. Antarctic echinoids frequently have specimens of species of the holothuroid Echinopsolus Gutt attached to the spines. Echinoids from BENTART-2003 and BENTART-2006 were being studied elsewhere when this 
holothuroid collection was being determined, and hence species of Echinopsolus Gutt from the Bellingshausen Sea and Antarctic Peninsula are not listed in this work.

In addition to working on the University of Málaga collection of Antarctic holothuroids, during 2008 Mark O'Loughlin has also determined large collections from the Ross Sea (held by the National Institute of Water and Atmospheric Research, NIWA, New Zealand), southern Atlantic (held by Museum Victoria, NMV, Australia), and Prydz Bay region (NMV). The holothuroid types from the Weddell Sea erected by Julian Gutt (1990) have been examined previously. From this work evidence of circum-polar distributions for most Antarctic holothuroid species has emerged. During this study, the opportunity was taken to review synonymies and generic referrals in this work. Contemporary synonymies for Antarctic holothuroid species, and a list of changed generic referrals for Antarctic dendrochirotid species, are listed. In the monograph on family Phyllophoridae by Heding \& Panning (1954), Albert Panning erected the genus Parathyonidium Heding and species Parathyonidium incertum Heding based on the notes of his deceased colleague Svend Heding who had hoped to write a report on the Discovery holothuroids. This species was found in the BENTART collections, and is discussed in this work.

\section{Methods}

Holotypes and paratypes and most of the specimens are lodged in the National Museum of Natural Sciences, Madrid (Museo Nacional de Ciencias Naturales, MNCN). Permanent slides of ossicles of the type species were prepared in Museum Victoria (NMV) by Mark O'Loughlin, and are registered and lodged in NMV with permission from Eugenia Manjón-Cabeza. Slide registrations numbers are listed with the descriptions below.

Digital photos of specimens were taken in the University of Málaga by Eugenia Manjón-Cabeza using a Nikon digital camera with microscope DXM1200F and Auto-Montage Pro software. Digital images of ossicles were taken in NMV by Chris Rowley, with Mark O'Loughlin, using a Leica DM5000 B compound microscope with Leica DC500 digital camera and Auto-Montage Pro software.

\section{Cucumariidae Blainville}

\section{Cucamba O'Loughlin gen. nov.}

Diagnosis. Genus of family Cucumariidae with 8 and 2 smaller tentacles; larger tube feet on 5 radii; smaller tube feet scattered on interradii; single-layered perforated plate body wall ossicles.

Type species. Cucumaria psolidiformis Vaney, 1908 (monotypic).

Etymology. From $C u c$ (first part of family name), with the Latin ambo (two together), referring to the two sizes of tube feet (feminine).

Remarks. In this work Caespitugo citriformis Gutt, 1990, the type species for Caespitugo Gutt, 1990, is judged to be a junior synonym of Thyone scotiae Vaney, 1906. Thyone scotiae Vaney is referred to Crucella Gutt, 1990. Caespitugo Gutt thus becomes a junior synonym of Crucella Gutt.

\section{Cucamba psolidiformis (Vaney) syn. nov., comb. nov.}

Table 1.

Cucumaria psolidiformis Vaney, 1908: 27-28, pl. 2 figs 17, 18, pl. 4 figs 51-53.-Ekman, 1925: 89-92, fig. 19._-Panning, 1949: 416.-_Panning, 1955: 38.-Pawson, 1969: pl. 22 map 2.

Cucumaria conspicua Vaney, 1908: 29, pl. 2 figs 15, 16, pl. 5 fig. 67.-Panning, 1949: 416.-Panning, 1955: 38.-Pawson, 1969: pl. 22 map 2 (new synonym).

Cucumaria armata Vaney, 1908: 31-32, pl. 5 figs 57, 58 (new synonym). 
Caespitugo diversipes Gutt, 1990: 102-104, figs 1-4, table 1.—Gutt, 1991: 323-324.—O'Loughin et al., 1994: 549, 555, table 2 (new synonym).

Remarks. Cucumaria psolidiformis Vaney, 1908 has a circum-polar distribution (M. O'Loughlin pers. obs.). The distinguishing characters of Cucumaria psolidiformis Vaney and Caespitugo diversipes Gutt, 1990 are: hard parchment-like body wall; long thin tail; mouth and anus terminal; 10 dendritic tentacles with ventral pair small; distinctive radial tube feet; inconspicuous interradial tube feet; irregular, perforated, elongate, narrow, thick, knobbed, single-layered, body wall ossicles. Caespitugo diversipes Gutt, 1990 is judged to be a junior synonym of Cucumaria psolidiformis Vaney, 1908. Cucumaria psolidiformis Vaney, 1908 is referred to Cucamba O'Loughlin gen. nov. that has the diagnostic characters listed above.

O'Loughlin (2002) synonymised Cucumaria conspicua Vaney, 1908 with Psolicrux coatsi (Vaney, 1908). That synonymy is rejected here, based on a closer reading of the description by Vaney (1908) of the single small type specimen (10 $\mathrm{mm}$ long) that includes: large tube feet along the radii, and numerous very small tube feet over the interradii. The only Antarctic holothuroid with this type of tube foot arrangement is Cucumaria psolidiformis Vaney, 1908. On this basis Cucumaria conspicua Vaney, 1908 is a junior synonym of Cucumaria psolidiformis Vaney, 1908.

Ekman (1925) synonymised Cucumaria armata Vaney, 1908 with Cucumaria georgiana (Lampert, 1886), and $C$. armata has been included in the "Cucumaria georgiana (Lampert, 1886) group" created by Gutt (1988) and followed by Massin (1992). Cucumaria armata Vaney, 1908 is removed from that synonymy in this work. It is judged in this work to be a junior synonym of Cucumaria psolidiformis Vaney, 1908, based on the following characters described by Vaney (1908): large numbers of small, close dorso-lateral tube feet; large, thick, irregular, often narrow, knobbed perforated plates (characteristic of $C$. psolidiformis).

\section{Cucumaria dudexa O’Loughin \& Manjón-Cabeza sp. nov.}

Figure 1a-c; table 1.

Material examined. Holotype. East Bellingshausen Sea, R/V Hesperides, BENTART-2003, stn MB13B, $69.8223^{\circ} \mathrm{S}, 77.8320^{\circ} \mathrm{W}, 605 \mathrm{~m}, 15 \mathrm{Feb} 2003$, MNCN 29.04/125; tentacle ossicles slide NMV F161512; dorsal body ossicles slide F161513; ventral body ossicles slide F161514; dorsal body ossicles slide F161515.

Diagnosis. Specimen $35 \mathrm{~mm}$ long (tentacles withdrawn, preserved), sub-cylindrical, widest diameter 6 $\mathrm{mm}$; thin, flexible, calcareous, parchment-like body wall; distinct sole ventrally, slight "belly"; upturned oral cone, rounded distally, 2 soft dorso-lateral oral papillae, $0.6 \mathrm{~mm}$ long; upturned long tapered anal cone, 18 $\mathrm{mm}$ long, thin and rounded distally, 5 soft radial anal papillae $0.6 \mathrm{~mm}$ long; 10 dendritic tentacles, ventral pair small; tube feet confined to radii, well-developed close paired series bordering sole latero-ventrally, slightly more spread series mid-ventrally, ventral interradii bare, smaller sparse radial tube feet on oral and anal cones; calcareous ring with 10 plates; radial plates anteriorly digitiform, thin, wide posteriorly with triangular notch; interradial plates anteriorly elongate, thin, tapered, wide posteriorly with curved indentation.

Ossicles in body wall slightly imbricate plates; ossicles single-layered, irregular, predominantly elongate, thick, smooth, perforated plates, few up to 24 large to small perforations, lacking surface and marginal knobs and spines, up to $400 \mu \mathrm{m}$ long; similar dorsally and ventrally; rare plates with digitiform denticulation and small perforations at one end. Tube feet with small endplates, $176 \mu \mathrm{m}$ diameter, small perforations centrally, marginally denticulate perforated support plates, not rods, up to $176 \mu \mathrm{m}$ long. Tentacles ossicles thick to thin, curved to bent to concave, round to oval, perforated plates, not rods, plates with blunt marginal denticulations, lacking surface knobs and spines, plates up to $208 \mu \mathrm{m}$ long.

Colour (preserved). Off-white.

Distribution. Antarctica, east Bellingshausen Sea, $605 \mathrm{~m}$.

Etymology. From the Greek dudexa (twelve), to honour the Manjón-Cabeza family to whom this number is richly significant. 

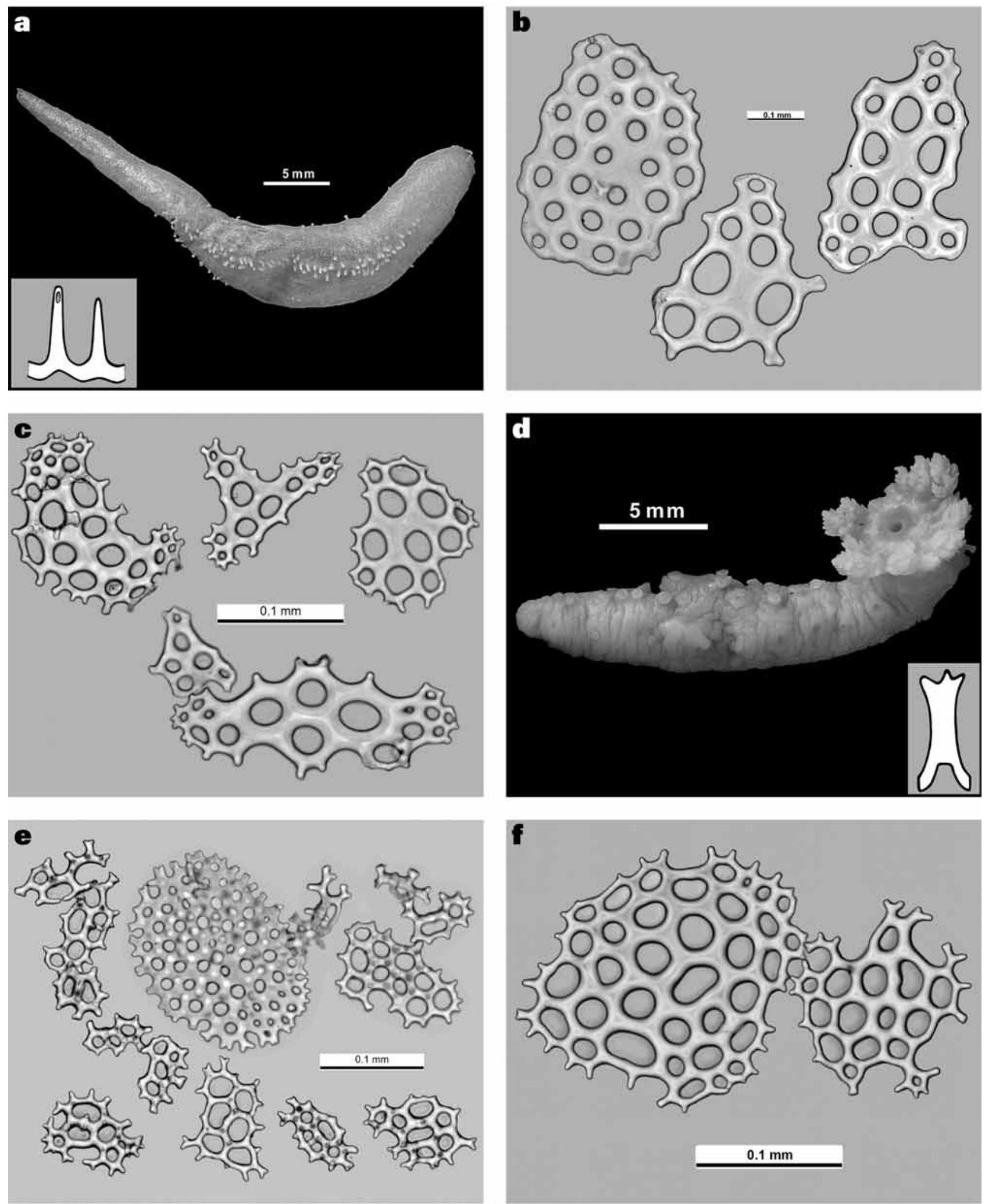

FIGURE 1. a-c, Cucumaria dudexa O'Loughin \& Manjón-Cabeza sp. nov.: a, holotype (MNCN 29.04/125), lateral view, oral end right, radial (left) and interradial plates of calcareous ring (insert); b, body wall ossicles (slides NMV F161513, F161514); c, tentacle ossicles (slide F161512). d-f, Parathyonidium incertum Heding, 1954: d, lateral view, radial plate of calcareous ring (insert) (MNCN 29.04/126); e, body wall ossicles (slide F161525); f, tentacle ossicles (slide F121567 from MNCN 29.04/127). 
Remarks. This new Antarctic dendrochirotid species is referred to Cucumaria Blainville because it has: 10 dendritic tentacles, ventral pair smaller; tube feet confined to radii; calcareous ring lacking posterior composite projections, ring plates with narrowing anterior projection and posterior indentation; body wall ossicles single-layered perforated plates. Antarctic Cucumaria species described to date have been grouped by Gutt (1988) and Massin (1992) into the "Cucumaria georgiana (Lampert, 1886) group". Cucumaria dudexa O’Loughin \& Manjón-Cabeza sp. nov. shares with this group the combination of eight large and two small tentacles, radial tube foot distribution, and single-layered perforated plates in the body wall. Cucumaria dudexa O'Loughin \& Manjón-Cabeza sp. nov. is distinguished from this group of species by the distinctive long thin tapered anal cone, presence of a discrete sole, and absence of knobs and spines on the perforated plate ossicles. Only a single specimen of Cucumaria dudexa sp. nov. was collected, but it is in very good condition and has distinct diagnostic characters.

\section{Parathyonidium incertum Heding}

Figure 1d-f; table 1.

Parathyonidium incertum Heding (in Heding \& Panning, 1954): 37-39, fig. 3.

Material examined. Antarctic Peninsula, Low I., BENTART-2006, R/V Hesperides, stn LOW47, 63.4668 ${ }^{\circ}$, 62.2151 ${ }^{\circ} \mathrm{W}, 115 \mathrm{~m}, 12 \mathrm{Feb} 2006, \mathrm{MNCN} 29.04 / 126$ (1 specimen), body wall ossicles slide NMV F161525; MNCN 29.04/127 (2 specimens), posterior body ossicles slide F161526, tentacle ossicles slide F161527; South Atlantic Ocean, South Georgia, Icefish 2004, stn 47 BT25, 114-118 m, 12 Jun 2004, NMV F104998 (1).

Diagnosis. Specimens up to $35 \mathrm{~mm}$ long (tentacles partly extended, preserved, NMV F104998), subcylindrical, elongate, widest diameter $5 \mathrm{~mm}$; soft thick non-calcareous body wall; lacking distinct sole ventrally; oral end sometimes upright, slightly tapered and rounded distally when tentacles withdrawn; anal end slightly tapered and rounded distally; 15 dendritic tentacles (variable; "type" has 13; F104998 has 16), unequal, some undeveloped (buds only); long digitiform genital papilla posterior to dorsal tentacle pair in male specimen (indicative of internal fertilization and brood protection); tube feet confined to radii, spaced single series of large tube feet, uniform in size from base of tentacles to anus; calcareous ring faintly evident, only radial plates evident, wide anteriorly and posteriorly, narrowed in mid-plate, 2 small notches anteriorly, deep rounded notch posteriorly.

Ossicles in body wall abundant, thin, bluntly spinous to smooth, single-layered irregular plates, few to many perforations; similar dorsally and ventrally; common form elongate, with 2 large central perforations, 2 small distal perforations, one extended end with few small perforations, short blunt spines on surface and around margin, typically $100 \mu \mathrm{m}$ long; small plates intergrade with larger smooth to knobbed, marginally denticulate plates, up to $200 \mu \mathrm{m}$ long. Tube foot endplates large, up to $360 \mu \mathrm{m}$ diameter, few perforated support plates, not rods. Tentacles ossicles perforated plates, not rods, round to oval, slightly concave, blunt marginal denticulations, some with central knob, some fine surface knobs, plates up to $200 \mu \mathrm{m}$ long.

Colour. Live: semi-translucent pale brown. Preserved: pale grey.

Distribution. South Georgia, Antarctic Peninsula (Low I.), 114-199 m.

Remarks. In Heding \& Panning (1954, p. 37) Panning notes that Heding died before their MS was completed, and before Heding was able to work on a Discovery Report. Panning wrote that he erected the new genus Parathyonidium Heding, 1954 and new species Parathyonidium incertum Heding, 1954 based on the notes by Heding, and with the approval of Dr. Deichmann (Harvard University). The specimens (obviously more than one) for this new genus and species were from Discovery-Expedition Stat. 474, one sea mile west of Shag Rock, South Georgia, $199 \mathrm{~m}$. No registration numbers are recorded, or precise number of specimens, but a "Type" is referred to. The descriptions are diagnostic and accord closely with the description above, except that no measurements were given for specimens or ossicles. Panning wrote that the work on the 
Discovery material was taken over by Dr. Deichmann. This was not completed, and no Discovery Report has been published. All of the Discovery holothuroids that remained on loan to the Smithsonian US National Museum of Natural History are currently (December 2008) in Museum Victoria for determination, on their way back to the British Museum of Natural History. The types for Parathyonidium incertum Heding, 1954 are not with the Discovery lots currently in Museum Victoria. It is reported (David Pawson, pers. comm.) that a paratype from Elephant Island is in the Paris Museum. The holotype has not been located.

\section{Psolicrux coatsi (Vaney, 1908)}

Figure 2d; table 1.

Remarks. Ekman (1925) synonymised Cucumaria aspera Vaney, 1908 with Psolidium (Cucumaria) coatsi Vaney, 1908. This synonymy was not recognized in the Psolicrux coatsi (Vaney, 1908) synonymy in O'Loughlin (2002). That omission is supported in this work. The small type specimen (11 mm long) of Cucumaria aspera Vaney, 1908 belongs as an additional species in the "Cucumaria georgiana (Lampert, 1886) group" created by Gutt (1988) and adopted by Massin (1992), based on the following characters described by Vaney (1908): tube feet confined to radial series; eight and two small ventral tentacles; irregular perforated plate ossicles, with some knobs.

Cucumaria conspicua Vaney, 1908 is removed from the Psolidium (Cucumaria) coatsi Vaney, 1908 synonymy by O'Loughlin (2002), and referred above to Cucamba psolidiformis (Vaney, 1908).

\section{Psolicrux iuvenilesi O’Loughin \& Manjón-Cabeza sp. nov.}

Figure 2a-c; table 1.

Material examined. Holotype. Antarctic Peninsula, Gerlache Strait, BENTART-2003, R/V Hesperides, stn PA23, $64.9255^{\circ} \mathrm{S}, 63.6068^{\circ} \mathrm{W}, 656 \mathrm{~m}, 25 \mathrm{Feb} 2003$, MNCN 29.04/128; dorsal body ossicles slide NMV F161522; ventral body ossicles slide F161523; tentacle ossicles slide F161524.

Paratypes. Type locality and date, MNCN 29.04/129 (4).

Other material. Paraiso Bay, R/V Hesperides, stn BP21, $64.90^{\circ} \mathrm{S}, 63.01^{\circ} \mathrm{W}, 101 \mathrm{~m}, 23 \mathrm{Feb} 2003$. Eastern Antarctica, Prydz Bay, Fram Bank, 444-453 m, 26 Feb 1991, F68053 (1); Enderby Land, 386-400, 15 Nov 1985, F84985 (1).

Diagnosis. Specimens up to $29 \mathrm{~mm}$ long (tentacles withdrawn), widest diameter $11 \mathrm{~mm}$; thin, flexible, calcareous, body wall with minute projecting spines; distinct sole and "belly" ventrally; oral cone, tapered anal cone forming distinct "tail", both oral and anal cones frequently upturned; 10 subequal dendritic tentacles; large tube feet in mid-ventral and latero-ventral paired radial series defining a distinct sole with broad bare interradii; single latero-ventral row (of the paired series) bordering the bare interradii typically close, outer row of paired series more spaced; smaller tube feet scattered dorsally and laterally and on oral and anal cones; tube feet do not cross introvert; radial plates of calcareous ring elongate, sub-rectangular, with deep posterior notch; interradial plates elongate, tapered and rounded anteriorly, with shallow rounded indentation posteriorly.

Ossicles in body wall numerous, imbricate, large, thick, single-layered, perforated, smooth plates with angled narrow distally spinous spire, plate and spire up to $480 \mu \mathrm{m}$ long, spires typically $160 \mu \mathrm{m}$ long; plates irregular in size and form; spired plates similar dorsally and ventrally; lacking small branched bluntly spinous rods and crosses. Largest tentacle ossicles irregularly oval to elongate, thick, knobbed, curved, perforated plates, up to $640 \mu \mathrm{m}$ long; smallest plates thin, smooth, marginally bluntly denticulate.

Colour (preserved). Pale grey-brown.

Distribution. Western Antarctica (Gerlache Strait), Eastern Antarctica (Fram Bank); 101-656 m. 

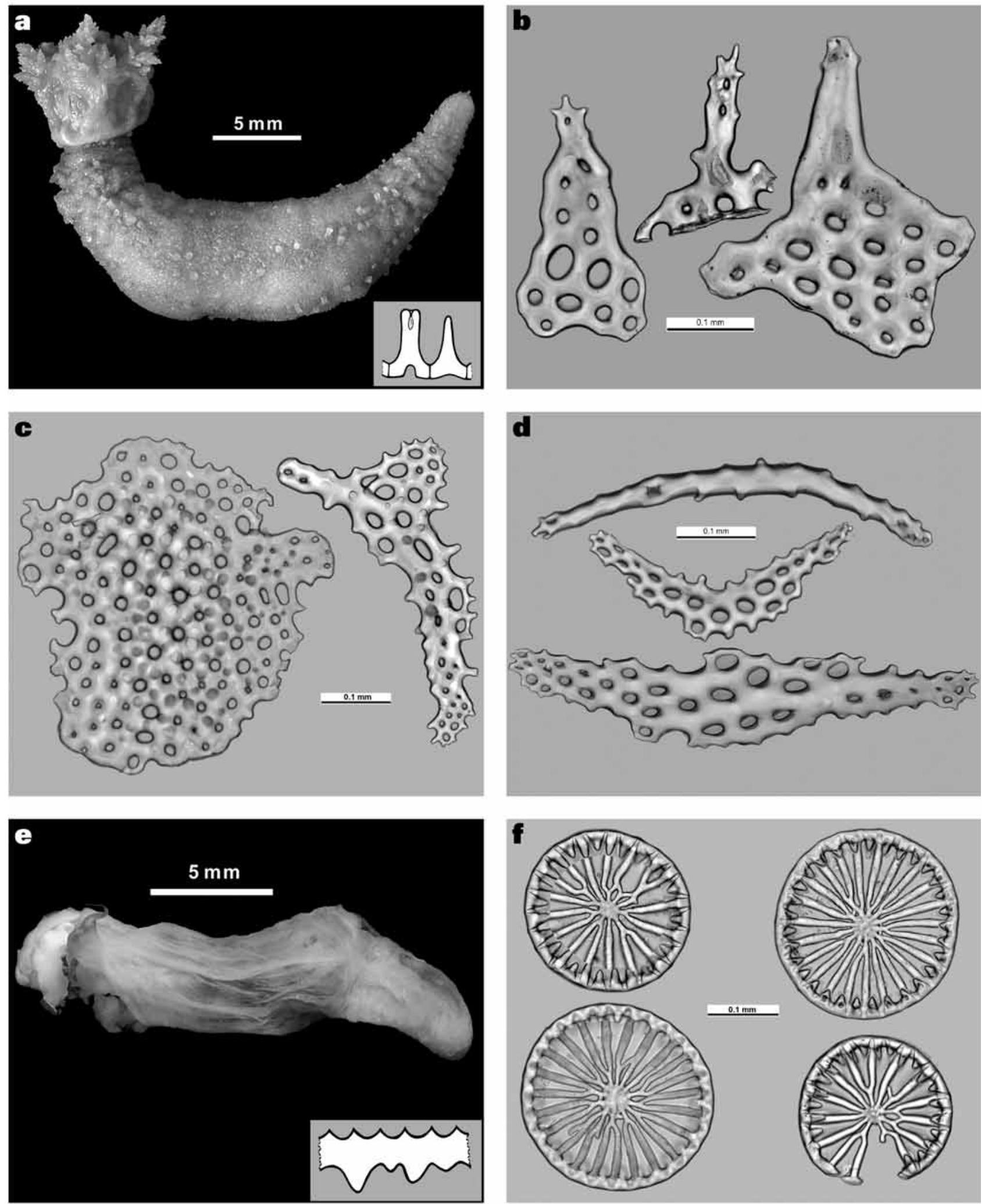

FIGURE 2. a-c, Psolicrux iuvenilesi O’Loughin \& Manjón-Cabeza sp. nov.: a, holotype (MNCN 20.04/128), lateral view, radial (left) and interradial plates of the calcareous ring (insert); b, spired plates (slide F161523 from holotype) and spire from body wall (slide from specimen F68053); c, tentacle ossicles (slide from specimen F68053).d, Psolicrux coatsi (Vaney, 1908): tentacle ossicles (slide from specimen F160026).e, f, Myriotrochus hesperides O'Loughin \& Manjón-Cabeza sp. nov.: e, holotype (MNCN 29.04/130), oral end with calcareous ring left, asymmetrical plates of calcareous ring (insert); f, wheels from posterior dorsal body wall (slide F161516). 
Etymology. From the Latin iuveniles (young people) in recognition of the skilled assistance provided by the young University of Málaga students Blanca Gallego Tevar, Carolina Yuste Florido and Juan Miguel Pérez Ramos.

Remarks. O'Loughlin (2002) reviewed Psolidium (Cucumaria) coatsi Vaney, 1908, erected the new genus Psolicrux for the species, and judged that Cucumaria conspicua Vaney, 1908, Psolidium navicula Ekman, 1927 and Psolidium bistriatum Ludwig \& Heding, 1935 were junior synonyms. Cucumaria conspicua Vaney, 1908 is removed above from the synonymy by O'Loughlin (2002), and referred to Cucamba psolidiformis (Vaney, 1908).

Body form, knobbed cross ossicles and spired plate ossicles of Psolicrux coatsi (Vaney, 1908) were illustrated by O'Loughlin (2002, figs 3c-f). In examining the material for that work it was noted that knobbed crosses were sometimes not found, and this was judged to be a sampling artefact (O'Loughlin, pers. obs.). In this work there has been a consistent absence of knobbed crosses in some specimens. The specimens lacking knobbed crosses are referred to the new species Psolicrux iuvenilesi O'Loughin \& Manjón-Cabeza sp. nov. In addition to the absence of knobbed crosses, the specimens are smaller, and the largest tentacle ossicles are thick knobbed oval to elongate plates while in Psolicrux coatsi (Vaney) the largest tentacle ossicles are thick, narrow, bluntly spinous, perforated rods, up to $536 \mu \mathrm{m}$ long (Figure $2 \mathrm{~d}$ ).

\section{Psolidiella mollis (Ludwig \& Heding)}

Table 1.

Pseudocholochirus mollis Ludwig \& Heding, 1935: 204-209, figs 62-65.-O’Loughlin, 2000: 25.

Psolidiella mollis._Panning, 1949: 415.-Pawson, 1969: 37, pl. 22 map 1.—Pawson, 1970: 36.-Gutt, 1988: 22.-Gutt, 1991: 323, 324.

Remarks. Panning (1949) referred Pseudocolochirus mollis Ludwig \& Heding, 1935 to Psolidiella Mortensen, 1925a. In a subsequent treatment Panning (1971) did not include P. mollis in Psolidiella, but did not reassign the species. O'Loughlin (2000) reviewed Psolidiella and, being unfamiliar with P. mollis, followed Panning (1971) and omitted P. mollis from Psolidiella. Current familiarity with the species confirms the original referral by Panning (1949) of Pseudocolochirus mollis Ludwig \& Heding, 1935 to Psolidiella Mortensen, 1925a.

\section{Staurocucumis turqueti (Vaney)}

Cucumaria grandis Vaney, 1906b: 405.-Vaney, 1906c: 12-14.—Vaney, 1908: 24-25, pl. 4, figs 45, 46.—Vaney, 1914: 9-11, pl. 2, fig. 10.-Cherbonnier, 1941: 571-573.

Cucumaria turqueti Vaney, 1906b: 406.- Vaney, 1906c: 18-19, fig. 1.—Ekman, 1925: 45-49, fig. 8.—Cherbonnier, 1941: 571-573.

Staurocucumis turqueti.—Ekman, 1927: 381-384, fig. 9.-Hansen, 1988: 303, 304, fig. 2.-Massin, 1994: 130, 132, fig. 2.

Cucumaria spatha Cherbonnier, 1941: 571-573.

Ekmocucumis turqueti.-Heding, 1942: 33.-Panning, 1949: 453.-Pawson, 1969: pl. 22 map 4.—Gutt, 1991: 323, 324.

Ekmocucumis spatha.-Panning, 1949: 453.-Pawson, 1969: pl. 22 map 4.-Cherbonnier, 1974: 602.

Ekmocucumis grandis.-Cherbonnier, 1974: 602.

Abyssocucumis turqueti.-Gutt, 1988: 22.

Ekmocucumis sp. MoV 2085.-O’Loughlin et al., 1994: 551, 555, table 2.

Remarks. Ekman (1925) made Cucumaria grandis Vaney, 1906b a junior synonym of Cucumaria turqueti Vaney, 1906b, although C. grandis has page precedence in Vaney (1906b). Since Ekman (1925) was the first reviser the synonymy is valid. Cherbonnier (1941) retained Cucumaria grandis Vaney but replaced the name 
with Cucumaria spatha, judging incorrectly that Vaney (1906b) used an invalid name. The original synonymy by Ekman (1925) is confirmed here.

\section{Myriotrochidae Théel}

\section{Myriotrochus hesperides O’Loughin \& Manjón-Cabeza sp. nov.}

Figure 2e, f: table 1.

Material studied. Holotype. Antarctic Peninsula, BENTART-2006, R/V Hesperides, stn PA41, 65.47149 ${ }^{\circ}$, $69.0285^{\circ} \mathrm{W}, 350 \mathrm{~m}, 10 \mathrm{Feb} 2006$, MNCN 29.04/130; posterior dorsal body ossicles slide NMV F161516.

Diagnosis. Specimen $13 \mathrm{~mm}$ long; thin translucent body wall; sub-cylindrical, dorsal oral ring projecting anteriorly over ventral, body rounded distally; 12 peltato-digitate tentacles, each tentacle with about 7 small rounded digits; plates of calcareous ring asymmetrical, with short pointed anterior projections, wide rounded tongue-like posterior projections of variable length, 2 radial plates each with 2 anterior projections.

Tentacles lacking ossicles; body wall ossicles a few wheels only in the posterior dorsal body wall; wheels of one type, with teeth all pointing towards centre of hub; spokes irregular, about half branching proximally, some branches not reaching rim, some spokes with cross-connections; teeth variably sub-equal or different in size; hubs small, irregular, not disc-like, lacking perforations, formed by junction of spokes; largest wheel with diameter $248 \mu \mathrm{m}$, hub diameter $40 \mu \mathrm{m}, 13$ spokes at hub, 23 spokes at rim, 30 equal teeth; smallest wheel with diameter $200 \mu \mathrm{m}$, hub diameter $24 \mu \mathrm{m}, 12$ spokes at hub, 16 spokes at rim, 28 unequal teeth.

Colour (preserved). Off-white, translucent; tentacle digit ends reddish-brown.

Distribution. Antarctic Peninsula, $350 \mathrm{~m}$.

Etymology. Named, as a noun in apposition, for the Spanish R/V Hesperides used for BENTART-2003 and BENTART-2006.

Remarks. Based on the key to the genera of family Myriotrochidae in Gage \& Billett (1986), this new myriotrochid species is referred to Myriotrochus Steenstrup because it has: 12 tentacles; asymmetrical calcareous ring, with 2 radial plates each with 2 anterior projections; absence of rod ossicles; wheel hubs lacking perforations; wheel ossicles of one type only, with all teeth pointed towards centre of hub.

Three specimens of myriotrochid holothuroid have been taken in Antarctica. Smirnov and Bardsley (1997) described Myriotrochus antarcticus from a $2 \mathrm{~mm}$ long specimen from the MacRobertson Shelf in eastern Antarctica at $113 \mathrm{~m}$. The wheels are 140-150 $\mu \mathrm{m}$ in diameter, have 22-24 teeth, and 15-16 unbranched spokes, different to Myriotrochus hesperides O'Loughin \& Manjón-Cabeza sp. nov. A New Zealand National Institute of Water and Atmospheric Research (NIWA) single specimen of a Myriotrochus species (registration NIWA 37812, two pieces, combined length $33 \mathrm{~mm}$ ) was taken in the Ross Sea at $2283 \mathrm{~m}$ in 2008. The wheel diameters are 320-395 $\mu \mathrm{m}$, have about 30 teeth, have 11-15 unbranched spokes and a perforated spoked hub, also different to Myriotrochus hesperides O'Loughin \& Manjón-Cabeza sp. nov. that is characterised by wheels with a small unperforated hub and frequently proximally branched spokes. The single type specimen is damaged, but appears to be intact, and has a complete oral end.

Myriotrochus hesperides O’Loughin \& Manjón-Cabeza sp. nov. has some characters that are similar to Myriotrochus clarki Gage \& Billett, 1986 from the Rockall Trough in the NE Atlantic at 1605-2515 m. Both species have large tongue-like posterior projections on the calcareous ring, but these are larger in $M$. hesperides and the anterior projections smaller. An "abnormal" wheel with a few distally branched spokes is illustrated for M. clarki, but all the M. hesperides wheels have numerous proximally branched spokes. 


\section{Paracucumidae Pawson \& Fell}

Crucella scotiae (Vaney) syn. nov., comb. nov.

Table 1.

Thyone scotiae Vaney, 1906a: 400-401, fig. 1._Ekman 1925: 106-108, fig. 24.

Ypsilocucumis scotiae.—Panning, 1949: 455.-Pawson, 1969: map 3.

Caespitugo citriformis Gutt, 1990: 105, figs 1, 5-7, table 2.-Gutt, 1991: 324 (new synonym).

Crucella cf. hystrix Gutt, 1990.-O'Loughlin et al., 1994: 552, table 2.

Remarks. Thyone scotiae Vaney, 1906a has a circum-polar distribution (M. O'Loughlin, pers. obs.). The distinguishing characters of Thyone scotiae Vaney, 1906a and Caespitugo citriformis Gutt, 1990 are: body with narrowed tail; hard to parchment-like body wall; 10 tentacles with ventral pair small; cucumariid not phyllophorid calcareous ring; tube feet evenly distributed around body; body wall ossicles small knobbed plates, large irregular thick knobbed perforated plates with central secondary mesh thickening; posterior body with multi-layered ossicles. Caespitugo citriformis Gutt, 1990 is judged here to be a junior synonym of Thyone scotiae Vaney, 1906a. Thyone Oken is an inappropriate genus for Thyone scotiae Vaney, since the calcareous rings of Thyone species have elongate composite posterior projections characteristic of family Phyllophoridae. Panning (1949) inappropriately referred T. scotiae to his new genus Ypsilothuria, diagnosed as having 10 equal tentacles. Thyone scotiae Vaney is referred here to Crucella Gutt, 1990 that has: body with narrowed tail; hard to parchment-like body wall; 10 tentacles with ventral pair small; cucumariid not phyllophorid calcareous ring; tube feet evenly distributed around body; body wall ossicles crosses with four perforated arms, with or without central secondary mesh thickening and spine. Gutt (1990) referred his now junior synonym species $C$. citriformis to his genus Caespitugo, but it is judged here that the senior synonym $T$. scotiae is more appropriately referred to Crucella Gutt, 1990 because of the multi-layering in the centre of some perforated plates, and some plates cross-shaped or with irregular arms. Caespitugo Gutt, 1990 becomes a junior synonym of Crucella Gutt, 1990.

\section{Contemporary synonymies for Antarctic holothuroid species (since 1994)}

Achlyonice violaecuspidata Gutt, 1990 = Rhipidothuria racowitzai Hérouard, 1901 (by Gebruk \& Shirshov, 1994)

Bathyplotes fuscivinculum Gutt, 1990 = Bathyplotes bongraini Vaney, 1914 (by O'Loughlin, 2002)

Bathyplotes rubipunctatus Gutt, 1990 = Bathyplotes gourdoni (Vaney, 1914) (by O'Loughlin, 2002)

Caespitugo citriformis Gutt, $1990=$ Thyone scotiae Vaney, 1906a (this work)

Caespitugo diversipes Gutt, 1990 = Cucumaria psolidiformis Vaney, 1908 (this work)

Cucumaria armata Vaney, 1908 = Cucumaria psolidiformis Vaney, 1908 (this work)

Cucumaria aspera Vaney, 1908 = Cucumaria georgiana (Lampert, 1886) group (this work)

Cucumaria conspicua Vaney, 1908 = Cucumaria psolidiformis Vaney, 1908 (this work)

Cucumaria grandis Vaney, 1906b = Cucumaria turqueti Vaney, 1906b (by Ekman, 1925; confirmed this work)

Cucumaria mira Ludwig \& Heding, 1935 = Cucumaria liouvillei Vaney, 1914 (by O’Loughln, 2002)

Paracucumis antarctica Mortensen, 1925b = Thyone turricata Vaney, 1906a (by O'Loughlin, 2002)

Psolidium navicula Ekman, 1927 = Psolidium bistriatum Ludwig \& Heding, 1935 = Psolidium (Cucumaria) coatsi Vaney, 1908 (by O’Loughlin, 2002) 
TABLE 1. List of holothuroids from BENTART-2003 (30 January to 27 February 2003) and BENTART-2006 (20 January to 13 February, 2006).

\begin{tabular}{|c|c|c|c|c|c|}
\hline Taxon & Station & Location & $\begin{array}{r}\text { Latitude } \\
{ }^{\circ} \mathrm{S}\end{array}$ & $\begin{array}{r}\text { Longitude } \\
{ }^{\circ} \mathrm{W}\end{array}$ & $\begin{array}{r}\text { Depth } \\
m\end{array}$ \\
\hline \multicolumn{6}{|l|}{ Apodida Brandt } \\
\hline Myriotrochus hesperides sp. nov. & PA41A & Antarctic Peninsula & -65.47 & -69.03 & 350 \\
\hline \multirow[t]{15}{*}{ Paradota weddellensis Gutt, 1990} & LOW46 & Low Island & -63.44 & -62.24 & 97 \\
\hline & MB13B & Bellingshausen Sea & -69.82 & -77.83 & 605 \\
\hline & MB33 & Bellingshausen Sea & -70.29 & -84.28 & 430 \\
\hline & MB9 & Bellingshausen Sea & -70.24 & -81.77 & 540 \\
\hline & PA18 & Marguerite Bay & -67.96 & -71.06 & 357 \\
\hline & PA23 & Gerlache Strait & -64.93 & -63.61 & 656 \\
\hline & PA24 & Gerlache Strait & -64.33 & -61.97 & 1054 \\
\hline & PA25 & Gerlache Strait & -63.88 & -61.81 & 115 \\
\hline & PA39 & Antarctic Peninsula & -68.13 & -69.59 & 167 \\
\hline & PA40A & Antarctic Peninsula & -66.96 & -72.58 & 402 \\
\hline & PA41A & Antarctic Peninsula & -65.47 & -69.03 & 350 \\
\hline & PI28 & Peter I Island & -68.87 & -90.30 & 1191 \\
\hline & PI5 & Peter I Island & -68.94 & -90.59 & 124 \\
\hline & PI6B & Peter I Island & -68.84 & -90.82 & 218 \\
\hline & PI7 & Peter I Island & -68.70 & -90.69 & 375 \\
\hline \multicolumn{6}{|l|}{ Aspidochirotida Grube } \\
\hline \multirow[t]{8}{*}{ Bathyplotes bongraini Vaney, 1914} & PA 18 & Marguerite Bay & -67.96 & -71.06 & 357 \\
\hline & PA23 & Gerlache Strait & -64.93 & -63.61 & 656 \\
\hline & PA39 & Antarctic Peninsula & -68.13 & -69.59 & 167 \\
\hline & PA39-2 & Antarctic Peninsula & -68.13 & -69.59 & 159 \\
\hline & $\mathrm{PA} 40 \mathrm{~A}$ & Antarctic Peninsula & -66.96 & -72.58 & 402 \\
\hline & PA41A & Antarctic Peninsula & -65.47 & -69.03 & 350 \\
\hline & PA43 & Antarctic Peninsula & -63.36 & -64.29 & 254 \\
\hline & PI27 & Peter I Island & -69.00 & -90.43 & 1873 \\
\hline \multirow[t]{4}{*}{ Bathyplotes gourdoni (Vaney, 1914) } & MB13B & Bellingshausen Sea & -69.82 & -77.83 & 605 \\
\hline & MB34 & Bellingshausen Sea & -70.12 & -84.87 & 603 \\
\hline & PA1 8 & Marguerite Bay & -67.96 & -71.06 & 357 \\
\hline & PI8 & Peter I Island & -68.83 & -90.35 & 86 \\
\hline \multirow[t]{2}{*}{ Bathyplotes moseleyi (Théel, 1886) } & PA19 & Marguerite Bay & -68.07 & -78.95 & 513 \\
\hline & PA23 & Gerlache Strait & -64.93 & -63.61 & 656 \\
\hline Bathyplotes sp. 1 undescribed & MB34B & Bellingshausen Sea & -70.12 & -84.87 & 603 \\
\hline Bathyplotes sp. 2 undescribed & PA41A & Antarctic Peninsula & -65.47 & -69.03 & 350 \\
\hline \multirow[t]{8}{*}{ Mesothuria bifurcata Hérouard, 1901} & MA4 & Amundsen Sea & -70.87 & -98.44 & 427 \\
\hline & MB13B & Bellingshausen Sea & -69.82 & -77.83 & 605 \\
\hline & MB2 & Thurston Island & -70.49 & -95.24 & 722 \\
\hline & MB26 & Bellingshausen Sea & -70.24 & -95.03 & 1958 \\
\hline & MB31 & Bellingshausen Sea & -69.96 & -86.40 & 1407 \\
\hline & MB33 & Bellingshausen Sea & -70.29 & -84.28 & 430 \\
\hline & MB36 & Bellingshausen Sea & -69.93 & -80.41 & 559 \\
\hline & MB9 & Bellingshausen Sea & -70.24 & -81.77 & 540 \\
\hline \multicolumn{6}{|l|}{ Dendrochirotida Grube } \\
\hline \multirow[t]{4}{*}{ Cucamba psolidiformis (Vaney, 1908) } & BP21 & Paraiso Bay & -64.90 & -63.01 & 101 \\
\hline & LOW47 & Low Island & -63.47 & -62.22 & 115 \\
\hline & PA39-2 & Antarctic Peninsula & -68.13 & -69.59 & 159 \\
\hline & PI6B & Peter I Island & -68.84 & -90.82 & 218 \\
\hline
\end{tabular}




\begin{tabular}{|c|c|c|c|c|c|}
\hline \multicolumn{6}{|l|}{ Dendrochirotida Grubc (continued) } \\
\hline Crucella hystrix Gutt, 1990 & MB34B & Bellingshausen Sea & -70.12 & -84.87 & 603 \\
\hline \multirow[t]{4}{*}{ Crucella scotiae (Vaney, 1906) } & $\mathrm{BP} 21$ & Paraiso Bay & -64.90 & -63.01 & 101 \\
\hline & LOW44 & Low Island & -63.43 & -62.20 & 82 \\
\hline & LOW45 & Low Island & -63.43 & -62.21 & 86 \\
\hline & LOW46 & Low Island & -63.44 & -62.24 & 97 \\
\hline \multirow[t]{6}{*}{ Cucumaria attenuata Vaney, 1906} & LOW44 & Low Island & -63.43 & -62.20 & 82 \\
\hline & LOW45 & Low Island & -63.43 & -62.21 & 86 \\
\hline & LOW46 & Low Island & -63.44 & -62.24 & 97 \\
\hline & LOW47 & Low Island & -63.47 & -62.22 & 115 \\
\hline & PI5 & Peter I Island & -68.94 & -90.59 & 124 \\
\hline & PI6B & Peter I Island & -68.84 & -90.82 & 218 \\
\hline Cucumaria dudexa sp. nov. & $\mathrm{MB} 13 \mathrm{~B}$ & Bellingshausen Sea & -69.82 & -77.83 & 605 \\
\hline \multirow[t]{5}{*}{ Heterocucumis denticulata (Ekman, 1927) } & LOW 44 & Low Island & -63.43 & -62.20 & 82 \\
\hline & LOW45 & Low Island & -63.43 & -62.21 & 86 \\
\hline & LOW46 & Low Island & -63.44 & -62.24 & 97 \\
\hline & LOW47 & Low Island & -63.47 & -62.22 & 115 \\
\hline & PI6B & Peter I Island & -68.84 & -90.82 & 218 \\
\hline \multirow[t]{5}{*}{ Heterocucumis steineni (Ludwig, 1898) } & $\mathrm{BP} 21$ & Paraiso Bay & -64.90 & -63.01 & 101 \\
\hline & LOW47 & Low Island & -63.47 & -62.22 & 115 \\
\hline & PA20 & Gerlache Strait & -65.02 & -63.42 & 48 \\
\hline & PA39-2 & Antarctic Peninsula & -68.13 & -69.59 & 159 \\
\hline & PA40A & Antarctic Peninsula & -66.96 & -72.58 & 402 \\
\hline \multirow[t]{5}{*}{ Paracucumis turricata (Vaney, 1906) } & $\mathrm{MB} 13 \mathrm{~B}$ & Bellingshausen Sea & -69.82 & -77.83 & 605 \\
\hline & $\mathrm{MB} 14 \mathrm{~B}$ & Bellingshausen Sea & -69.35 & -78.09 & 497 \\
\hline & MB36 & Bellingshausen Sea & -69.93 & -80.41 & 559 \\
\hline & PA18 & Marguerite Bay & -67.96 & -71.06 & 357 \\
\hline & PA25 & Gerlache Strait & -63.88 & -61.81 & 115 \\
\hline Parathyonidium incertum Heding, 1954 & LOW47 & Low Island & -63.47 & -62.22 & 115 \\
\hline \multirow[t]{4}{*}{ Psolicrux coatsi (Vaney, 1908) } & $\mathrm{BP} 21$ & Paraiso Bay & -64.90 & -63.01 & 101 \\
\hline & LOW47 & Low Island & -63.47 & -62.22 & 115 \\
\hline & PA20 & Gerlache Strait & -65.02 & -63.42 & 48 \\
\hline & PA23 & Paraiso Bay & -64.90 & -63.01 & 101 \\
\hline \multirow[t]{2}{*}{ Psolicrux iuvenilesi sp. nov } & BP21 & Paraiso Bay & -64.90 & -63.01 & 101 \\
\hline & PA23 & Gerlache Strait & -64.93 & -63.61 & 656 \\
\hline Psolidiella mollis (Ludwig \& Heding, 1935) & LOW47 & Low Island & -63.47 & -62.22 & 115 \\
\hline Psolidium gaini Vaney, 1914 & LOW46 & Low Island & -63.44 & -62.24 & 97 \\
\hline \multirow{7}{*}{$\begin{array}{l}\text { Psolidium pawsoni O'Loughlin \& Ahearn, } \\
\quad 2008\end{array}$} & MB2 & Thurston Island & -70.49 & -95.24 & 722 \\
\hline & MB3 & Thurston Island & -70.29 & -95.20 & 1435 \\
\hline & MB34 & Bellingshausen Sea & -70.12 & -84.87 & 603 \\
\hline & MB37 & Bellingshausen Sea & -69.43 & -80.41 & 508 \\
\hline & PA23 & Gerlache Strait & -64.93 & -63.61 & 656 \\
\hline & PA39 & Antarctic Peninsula & -68.13 & -69.59 & 167 \\
\hline & PA40A & Antarctic Peninsula & -66.96 & -72.58 & 402 \\
\hline \multirow[t]{5}{*}{ Psolidium tenue Mortensen, 1925} & $\mathrm{MB} 13 \mathrm{~B}$ & Bellingshausen Sea & -69.82 & -77.83 & 605 \\
\hline & MB3 & Thurston Island & -70.29 & -95.20 & 1435 \\
\hline & MB33 & Bellingshausen Sea & -70.29 & -84.28 & 430 \\
\hline & PA40A & Antarctic Peninsula & -66.96 & -72.58 & 402 \\
\hline & PA41A & Antarctic Peninsula & -65.47 & -69.03 & 350 \\
\hline \multirow{2}{*}{$\begin{array}{l}\text { Psolidium whittakeri O'Loughlin \& Ahearn, } \\
\quad 2008\end{array}$} & MB3 & Thurston Island & -70.29 & -95.20 & 1435 \\
\hline & $\mathrm{PI} 28$ & Peter I Island & -68.87 & -90.30 & 1191 \\
\hline \multirow[t]{3}{*}{ Psolus antarcticus (Philippi, 1857) } & MB31 & Bellingshausen Sea & -69.96 & -86.40 & 1407 \\
\hline & MB35 & Bellingshausen Sea & -69.93 & -85.16 & 1132 \\
\hline & PI28 & Peter I Island & -68.87 & -90.30 & 1191 \\
\hline
\end{tabular}




\begin{tabular}{|c|c|c|c|c|c|}
\hline \multicolumn{6}{|l|}{ Dendrochirotida Grube (continued) } \\
\hline \multirow[t]{4}{*}{ Psolus chacoti Vaney, 1906} & LOW45 & Low Island & -63.43 & -62.21 & 86 \\
\hline & LOW46 & Low Island & -63.44 & -62.24 & 97 \\
\hline & LOW47 & Low Island & -63.47 & -62.22 & 115 \\
\hline & PA39-2 & Antarctic Peninsula & -68.13 & -69.59 & 159 \\
\hline \multirow[t]{2}{*}{ Psolus dubiosus Ludwig \& Heding, 1935} & $\mathrm{BP} 21$ & Paraiso Bay & -64.90 & -63.01 & 101 \\
\hline & LOW47 & Low Island & -63.47 & -62.22 & 115 \\
\hline \multirow[t]{4}{*}{ Psolus koehleri Vaney, 1914} & BP21 & Paraiso Bay & -64.90 & -63.01 & 101 \\
\hline & LOW47 & Low Island & -63.47 & -62.22 & 115 \\
\hline & PA19 & Marguerite Bay & -68.07 & -78.95 & 513 \\
\hline & PA23 & Gerlache Strait & -64.93 & -63.61 & 656 \\
\hline Psolus sp. undescribed & PI28 & Peter I Island & -68.87 & -90.30 & 1191 \\
\hline \multirow[t]{10}{*}{ Staurocucumis liouvillei (Vaney, 1914) } & $\mathrm{BP} 21$ & Paraiso Bay & -64.90 & -63.01 & 101 \\
\hline & LOW47 & Low Island & -63.47 & -62.22 & 115 \\
\hline & PA18 & Marguerite Bay & -67.96 & -71.06 & 357 \\
\hline & PA20 & Gerlache Strait & -65.02 & -63.42 & 48 \\
\hline & PA39-2 & Antarctic Peninsula & -68.13 & -69.59 & 159 \\
\hline & PA40A & Antarctic Peninsula & -66.96 & -72.58 & 402 \\
\hline & PA41A & Antarctic Peninsula & -65.47 & -69.03 & 350 \\
\hline & PI5 & Peter I Island & -68.94 & -90.59 & 124 \\
\hline & PI6B & Peter I Island & -68.84 & -90.82 & 218 \\
\hline & PI8 & Peter I Island & -68.83 & -90.35 & 86 \\
\hline \multirow{4}{*}{$\begin{array}{l}\text { Trachythyone bouvetensis (Ludwig \& } \\
\quad \text { Heading, 1935) }\end{array}$} & BP21 & Paraiso Bay & -64.90 & -63.01 & 101 \\
\hline & LOW45 & Low Island & -63.43 & -62.21 & 86 \\
\hline & LOW47 & Low Island & -63.47 & -62.22 & 115 \\
\hline & PI5 & Peter I Island & -68.94 & -90.59 & 124 \\
\hline \multicolumn{6}{|l|}{ Elasipodida Théel } \\
\hline Benthodytes sanguinolenta Théel, 1882 & MB29 & Bellingshausen Sea & -69.40 & -88.34 & 3310 \\
\hline Elpidia glacialis Théel, 1876 & MB9 & Bellingshausen Sea & -70.24 & -81.77 & 540 \\
\hline Peniagone incerta (Théel, 1882) & MB29 & Bellingshausen Sea & -69.40 & -88.34 & 3310 \\
\hline \multirow[t]{10}{*}{ Peniagone vignoni Hérouard, 1901} & MA4 & Amundsen Sea & -70.87 & -98.44 & 427 \\
\hline & MB10B & Bellingshausen Sea & -70.74 & -81.47 & 497 \\
\hline & MB13B & Bellingshausen Sea & -69.82 & -77.83 & 605 \\
\hline & MB14B & Bellingshausen Sea & -69.35 & -78.09 & 497 \\
\hline & MB33 & Bellingshausen Sea & -70.29 & -84.28 & 430 \\
\hline & MB36 & Bellingshausen Sea & -69.93 & -80.41 & 559 \\
\hline & MB37 & Bellingshausen Sea & -69.43 & -80.41 & 508 \\
\hline & MB9 & Bellingshausen Sea & -70.24 & -81.77 & 540 \\
\hline & PA19 & Marguerite Bay & -68.07 & -78.95 & 513 \\
\hline & PA24 & Gerlache Strait & -64.33 & -61.97 & 1054 \\
\hline \multirow[t]{4}{*}{ Protelpidia murrayi (Théel, 1879) } & MB13B & Bellingshausen Sea & -69.82 & -77.83 & 605 \\
\hline & MB9 & Bellingshausen Sea & -70.24 & -81.77 & 540 \\
\hline & PA19 & Marguerite Bay & -68.07 & -78.95 & 513 \\
\hline & PA24 & Gerlache Strait & -64.33 & -61.97 & 1054 \\
\hline Psychropotes longicauda Théel, 1882 & MB29 & Bellingshausen Sea & -69.40 & -88.34 & 3310 \\
\hline \multicolumn{6}{|l|}{ Molpadida Haeckel } \\
\hline \multirow[t]{4}{*}{ Molpadia musculus Risso, 1826} & MB36 & Bellingshausen Sea & -69.93 & -80.41 & 559 \\
\hline & PA19 & Marguerite Bay & -68.07 & -78.95 & 513 \\
\hline & PA23 & Gerlache Strait & -64.93 & -63.61 & 656 \\
\hline & PA25 & Gerlache Strait & -63.88 & -61.81 & 115 \\
\hline Molpadia sp. undescribed & MB36 & Bellingshausen Sea & -69.93 & -80.41 & 559 \\
\hline
\end{tabular}




\section{Changed combinations for Antarctic dendrochirotid species}

Cucumaria abyssorum Théel, 1886a = Staurocucumis abyssorum (Théel, 1886a) (by Ekman, 1927; confirmed by Hansen, 1988)

Cucumaria denticulata Ekman, 1927 = Heterocucumis denticulata (Ekman, 1927) (by O'Loughlin, 2002)

Cucumaria godeffroyi Semper, 1868 = Heterocucumis godeffroyi (Semper, 1868) (by O'Loughlin, 2002)

Cucumaria liouvillei Vaney, 1914 = Staurocucumis liouvillei (Vaney, 1914) (by Ekman, 1927; confirmed by Hansen, 1988)

Cucumaria psolidiformis Vaney, 1908 = Cucamba psolidiformis (Vaney, 1908) (this work)

Cucumaria steineni Ludwig, 1898 = Heterocucumis steineni (Ludwig, 1898) (by Massin, 1994; O'Loughlin, 2002)

Cucumaria turqueti Vaney, 1906b = Staurocucumis turqueti (Vaney, 1906b) (by Ekman, 1927; confirmed by Hansen, 1988; confirmed this work)

Pseudocholochirus mollis Ludwig \& Heding, 1935 = Psolidiella mollis (Ludwig \& Heding, 1935) (by Panning, 1949; confirmed this work)

Psolidium (Cucumaria) coatsi Vaney, 1908 = Psolicrux coatsi (Vaney, 1908) (by O'Loughlin, 2002)

Thyone (Thyonidium) lechleri Lampert, $1885=$ Thyone hassleri Théel, 1886b $=$ Trachythyone lechleri (Lampert, 1885) (by Panning, 1949)

Thyone scotiae Vaney, 1906a = Crucella scotiae (Vaney, 1906a) (this work)

Thyone turricata Vaney, 1906a = Paracucumis turricata $($ Vaney, 1906a) (by O'Loughlin, 2002)

\section{Acknowledgments}

We are grateful for the contribution of the following to this work: Principal BENTART Researcher, Ana Ramos, and team who collected the holothuroid specimens; University of Málaga students Blanca Gallego Tevar, Carolina Yuste Florido and Juan Miguel Pérez Ramos who assisted significantly with the systematic determination of the specimens; Chris Rowley (NMV) for photography of ossicles; Ben Boonen for format of figures and table. We acknowledge with appreciation the funding by the Spanish Government of BENTART-2003 through Antarctic Programme REN2001-1074/ANT, and BENTART-2006 through Antarctic Programme GLC2004-01856/ANT; the funding of collection maintenance through Antarctic Programme CGL2004-04684/ANT; the funding of microscopic studies and photographs through Antarctic Programme CGL2004-21066-E; the funding of international collaboration by the Málaga University Projects (A.5. Mod. B). We are most appreciative of the insightful and very helpful comments offered by an anonymous reviewer.

\section{References}

Cherbonnier, G. (1941) Note sur Cucumaria spatha n. nom. (= C. grandis Vaney) et Cucumaria turqueti Vaney (Holothuries). Bulletin du Muséum national d'Histoire naturelle, Paris, 2(13)6, 571-574.

Cherbonnier, G. (1974) Invertébrés marins des XIIème et XVème expéditions antarctiques Françaises en Terre Adélie. 15. Holothurides. Tethys, 5(4), 601-610.

Ekman, S. (1925) Holothurien. Further zoological results of the Swedish Antarctic Expedition 1901-1903, 1(6), 1-194.

Ekman, S. (1927) Holothurien der deutschen Südpolar-Expedition 1901-1903 aus der Ostantarktis und von den Kerguelen. Deutsche Südpolar-Expedition, 19 (Zoology 11), 359-419.

Gage, J.D. \& Billett, D.M.S. (1986) The family Myriotrochidae Théel (Echinodermata: Holothurioidea) in the deep northeast Atlantic Ocean. Zoological Journal of the Linnean Society, 88, 229-276.

Gebruk, A. \& Shirshov, P.P. (1994) Revision of two deep-sea holothurian genera Psychrelpidia Hérouard, 1923 and Rhipidothuria Hérouard, 1901 (Elpidiidae). Mitteilungen aus dem Hamburgischen Zoologischen Museum und Institut, 91, 147-154. 
Gutt, J. (1988) Zur Verbreitung und Ökologie der Seegurken (Holothuroidea, Echinodermata) im Weddellmeer (Antarktis). Berichte zur Polarforschung, 41, 1-87.

Gutt, J. (1990) New Antarctic holothurians (Echinodermata) - I. Five new species with four new genera of the order Dendrochirotida. Zoologica Scripta, 19(1), 119-127.

Gutt, J. (1991) Are Weddell Sea holothurians typical representatives of the Antarctic benthos? Meeresforschung, 33(4), 312-329.

Hansen, B. (1988) The genus Staurocucumis Ekman and its possible affinity with Echinocucumis Sars (Holothuroidea, Dendrochirota). In: Burke, R.D., Mladenov, P.V., Lambert, P. \& Parsley, R.I. (Eds.), Echinoderm Biology. Balkema, Rotterdam, pp. 301-308.

Heding, S.G. (1942) Holothurioidea. II. Danish Ingolf-Expedition, 4(13), 1-39, pls 1-2.

Heding, S.G. \& Panning, A. (1954) Phyllophoridae. Eine bearbeitung der polytentaculaten dendrochiroten holothurien des zoologischen museums in Kopenhagen. Spolia Zoologica Musei Hauniensis, 13, 1-209.

Hérouard, E. (1901) Note préliminaire sur les holothuries rapportées par l'Expédition Antarctique Belge. Archives de Zoologie Expérimentale et Générale 3(9) Notes et Revue, 3(7), 39-48.

Lampert, K. (1885) Die Seewalzen. Holothurioidea. Eine Systematische Monographie. In: Semper, C. (Ed.), Reisen im Archipel der Philippinen, 4(3), 1-310, 1 pl.

Lampert, K. (1886) Die Holothurien von Süd-Georgien nach der Ausbeute der Deutschen Polarstation in 1882 und 1983. Jahrbuch Hamburgischen Wissenschaftlichen Anstalten, 3, 11-22.

Ludwig, H. (1898) Holothurien. Ergebnisse der Hamburger Magalhaensischen Sammelreise 1892/93, 1, 1-98, 3 pls.

Ludwig, H. \& Heding, S.G. (1935) Die holothurien der Deutschen Tiefsee-Expedition. 1. Fusslose und dendrochirote formen. Wissenschaftliche Ergeb-nisse der Deutschen Tiefsee-Expedition auf dem dampfer Valdivia 1898-1899, 24, 123-214.

Massin, Cl. (1992) Three new species of Dendrochirotida (Holothuroidea, Echinodermata) from the Weddell Sea (Antarctica). Bulletin de l'Institut Royal des Sciences Naturelles de Belgique, Biologie, 62, 179-191.

Massin, C. (1994) Ossicle variation in Antarctic dendrochirote holothurians (Echinodermata). Bulletin de l'Institut Royal des Sciences Naturelles de Belgique, Biologie, 64, 129-146.

Mortensen, T. (1925a) Echinoderms of New Zealand and the Auckland-Campbell Islands. III-V. Asteroidea, Holothurioidea, Crinoidea. Videnskabelige Meddelelser fra Dansk naturhistorisk Forening i Kobenhavn, 79(29), 261-420, text figs 1-70, pls 12-14.

Mortensen, T. (1925b) On a small collection of echinoderms from the Antarctic Sea. Arkiv för Zoologi, 17A(31), 12, 8 figs.

O'Loughlin, P.M. (2000) A review of the cucumariid genus Psolidiella Mortensen (Echinodermata, Holothuroidea). Memoirs of Museum Victoria, 58(1), 25-37.

O'Loughlin, P.M. (2002) Report on selected species of BANZARE and ANARE Holothuroidea, with reviews of Meseres Ludwig and Heterocucumis Panning (Echinodermata). Memoirs of Museum Victoria, 59(2), 297-325.

O'Loughlin, P.M. \& Ahearn, C. (2008) Antarctic and Sub-Antarctic species of Psolidium Ludwig (Echinodermata: Holothuroidea: Psolidae). Memoirs of Museum Victoria, 65: 23-42.

O’Loughlin, P.M., Bardsley, T.M. \& O’Hara, T.D. (1994) A preliminary analysis of diversity and distribution of Holothurioidea from Prydz Bay and the MacRobertson Shelf, eastern Antarctica. In: David, B., Guille, A., Féral, JP. \& Roux, M. (Eds.), Echinoderms through Time. Proceedings of the Eighth International Echinoderm Conference, Dijon, France, 6-10 September, 1993. Balkema: Rotterdam, pp. 549-555, 1 fig., 2 tables.

Panning, A. (1949) Versuch einer Neuordnung der Familie Cucumariidae (Holothurioidea, Dendrochirota). Zoologische Jahrbücher Abtheilung für Systematik, Geographie und Biologie der Thiere, 78, 404-470.

Panning, A. (1955) Bemerkungen über die Holothurien-Familie Cucumariidae (Ordnung Dendrochirota). Mitteilungen aus dem Hamburgischen Zoologischen Museum und Institut, 53, 33-47.

Panning, A. (1971) Bemerkungen über die holothurien-familie Cucumariidae (Ordnung Dendrochirota). 6. Die gattungen um Ocnus Forbes 1841 und um Pentacta Goldfuss 1820. Mitteilungen aus dem Hamburgischen Zoologischen Museum und Institut, 67, 29-51.

Pawson, D.L. (1969) Holothuroidea. In: Bushnell, V.C. \& J.W. Hedgpeth, J.W. (Eds.), Distribution of Selected Groups of Marine Invertebrates in Waters South of $35^{\circ}$ S Latitude. Antarctic Map Folio Series (II). American Geographical Society, New York, pp. 36-38, 1 pl.

Pawson, D.L. (1970) The marine fauna of New Zealand: Sea cucumbers (Echinodermata: Holothuroidea). Bulletin of the New Zealand Department of Scientific and Industrial Research, 201, 7-65, 10 figs, 2 pls.

Philippi, A. (1857) Vier neue Echinodermen des Chilenschen Meeres. Archiv Naturgeschicht, 23, 130-134.

Risso, A. (1826) Histoire naturelle des principales productions de l'Europe méridionales et particulièrment de celles des environs de Nice et des Alpes Maritimes. Levrault, Paris, 4, 439 pp.

Semper, C. (1868) Holothurien. Reisen im Archipel der Philippinen, 1, 1-288, pls 1-40.

Smirnov, A.V. \& Bardsley, T.M. (1997) Myriotrochus antarcticus sp. nov. (Apodida: Myriotrochidae), a new holothurian species from eastern Antarctica. Proceedings of the Royal Society of Victoria, 109(1), 109-111. 
Théel, H. (1876) Note sur l'Elpidia genre nouveau du groupe des Holothuries. Bihang Kungliga Svenska Vetenskapsakademiens Handlingar, 4(4), 7 pp.

Théel, H. (1879) Preliminary report on the Holothuridae of the exploring voyage of H.M.S. Challenger. 1. Bihang till Kongl.Svenska Vetenskaps-Akademiens Handlingar, 5(19), 1-20, pls 1-2.

Théel, H. (1882) Report on the Holothurioidea, 1. Report on the Scientific Results of the Voyage of H.M.S. Challenger, 1873-1876, Zoology, 4, 13, 1-176, pls 1-46.

Théel, H. (1886a) Report on the Holothurioidea dredged by H.M.S. Challenger during the years 1873-1876. Report on the scientific results of the voyage of H.M.S. Challenger, Zoology, 14(39), 1-290, 16 pls.

Théel, H. (1886b) Report on the Holothurioidea. Reports on the results of dredging, in the Gulf of Mexico (1877-1878), in the Caribbean Sea (1879-1880), and along the eastern coast of the United States, by the U.S. Coast Survey Steamer Blake. Bulletin of the Museum of Comparative Zoology at Harvard, 13(1)30, 1-21, 1 pl.

Vaney, C. (1906a) Deux nouvelles holothuries du genre Thyone provenant des Orcades du Sud. Bulletin du Muséum d'Histoire naturelle, Paris, 12, 400-402.

Vaney, C. (1906b) Note préliminaire sur les holothuries recueillies per l'Expédition Antarctique Française du Dr Charcot. Bulletin du Muséum D'Histoire naturelle de Paris, 12, 402-407.

Vaney, C. (1906c) Holothuries Expédition Antarctique Française (1903-1905). Sciences Naturelles: Documents Scientifiques, 30 pp., 2 pls, 1 map.

Vaney, C. (1908) Les Holothuries de l'Expédition Antarctique Nationale Écossaise. Transactions of the Royal Society of Edinburgh, 46, 405-441, 5 pls.

Vaney, C. (1914) Holothuries. Deuxième Expédition Antarctique Française (1908-10). Sciences Naturelles: Documents Scientifiques, 54 pp., 5 pls. 